\title{
Reinstatements of Retrenched Journals at the University of Ilorin Library
}

\section{Richard Olorunsola}

The rising costs of serials coupled with the devaluation of Nigeria's currency make subscribing to journals almost impossible for the country's academic libraries. In 1987, the University of Ilorin Library was forced to curtail its current journal acquisition program. Periodical holdings were listed and broken down into subject areas, and academic departments were asked to rank titles in order of their usefulness. The university library administration made final decisions. The administration initially decided to renew 287 journals (43.1\% of the original total) while canceling $379(56.9 \%)$. As a result of wide publicity about the dearth of books and journals in Nigerian universities, the federal government reached an agreement with the World Bank, which extended credit for the purchase of monographs and serials. After bureaucratic difficulties in ordering replacements, 384 titles were reinstated-five titles above what was retrenched. Unless the cost of the University Library's journals stops increasing or the library's books and periodicals budget expands, the library may face more sacrifices after the World Bank funding ceases.

$\mathbf{T}$ o start, it is important to note that the economies of most Third World countries have declined precipitously since the early 1980s. Since that time the funding climate for libraries in Third World countries has not been favorable, to say the least. Up until now, the situation has shown no appreciable signs of improvement. This has adversely affected the adequate provision of resources for most of these libraries. The rising costs of serials coupled with the devaluation of the naira make journal subscriptions almost unaffordable for academic libraries in Nigeria. Guides to the contents of periodicals-i.e., abstracts and indexes-are no exception; in fact, they are hardest hit. When, in 1986, the University of Ilorin began having difficulty in renewing its journals, the cost of Science Citation Index was between $\$ 3,000$ and $\$ 3,425$.

Puccio $(1989,194)$ has said that a serial's life within a particular library begins when a decision is made to start receiving the publication on a continuing basis. This is normally achieved though a paid subscription, which is often placed or maintained through a subscription agency. The decision to add a serial to a library's collection is usually made after careful consideration. Once a subscription begins, it becomes a standing charge against the 
library budget for an unforseeable period.

In 1987 the University of Ilorin Library was forced to curtail its current journal acquisition program for two reasons. First, in 1986 the government introduced a Structural Adjustment Programme that compelled all libraries to make their overseas journal and book purchases through the Foreign Exchange Market. Second, the inflation of serials prices increased more rapidly than previously, and additional funds were not made available for the books and periodicals budget.

It was estimated at the time that renewal costs for journals totaled $\$ 102,062.18$, while the annual budget for books and periodicals stood at just $\$ 63,798.27$ (Olorunsola and Ajileye 1990 , 42). Although library policy dictated that $80 \%$ of the books and periodicals budget was to be spent on serials, there was obviously no way to cover all the increased costs of serial renewals by further reducing the money spent on monographs. Consequently, the library was forced to prune its subscription list.

Behind the idea of allocating $80 \%$ of the available budget to serials is the realization that journals play a crucial role in research at academic libraries. The University of Ilorin's priorities are by no means unique. Puccio $(1989,21)$ has said that serials comprise a significant portion of the collection of most libraries and obligate a large percentage of the budgets of those libraries. Ward $(1975,243)$, in his study of seventeen London libraries, observed that the libraries spent between $24 \%$ and $90 \%$ of their budgets on periodicals purchases.

\section{Procedures for Cancellation}

The periodical holdings of the University of Ilorin Library were broken down into 36 subject areas. In all, 36 departments received lists of serials relevant to their interests. Each department was asked to rank the serials in order of their usefulness. This exercise was done in order to determine which journals were most urgently needed in the face of very lean budgets. The listed titles were ranked in four categories in order of priority. At the end of the exercise, the analysis of the ranking -in descending order of importance from $A$ to D-was as follows:
A 290
B 258
C 84
D 34
666 titles

The university library administration made final decisions based on those rankings. The administration renewed 287 of journals ranked A ( $43.1 \%$ of the original 666), while it canceled 379 (56.9\%) (Olorunsola and Ajileye 1990, 44).

\section{EFFEct of THE Cancellation Exercise}

The seriousness of the economies required by retrenchment was brought home to most members of the faculty because, with $56.9 \%$ of the serials cut, almost everyone had to do without one of "their" journals. Nevertheless, the serials librarian received serious verbal protests from many lecturers. Faculty members complained that current issues of certain journals were not available for use; in many cases, however, those serials were on the retrenched list. Some protested that damage had been done to the collection by the cancellation of unique titles. Others argued that they had not been informed of the ranking exercise that preceded the pruning. However, the university management had consulted with the heads of departments.

I observed some inadequacies in the cancellation procedure. The procedure should have considered some more scientific methods of selecting titles for cancellation, such as:

\section{- Citation frequency}

- Productivity ranking (Bradford's law of dispersion)

- Use surveys

- Cost analysis

- Abstract coverage

- Processing and storage costs 


\section{REINSTATEMENTS}

As a result of wide publicity about the dearth of books and journals in Nigerian universities, the federal government reached an agreement with the World Bank, which extended credit for the purchase of monographs and serials. The idea was to renew most journals that were discontinued due to a lack of funds. The credit was to be extended to all federal, government-funded universities that satisfied certain conditions laid down by the National Universities Commission. The University of Ilorin qualified and in 1990 the library began plans to draw from the credit. The serials librarian drafted a new subscription list based largely on the list of the journals canceled in 1987, although some new titles were added. The serials librarian ordered 500 titles worth some $\$ 109,890.82$. To bridge the gaps created in the library's journal file, some backfiles worth about $\$ 196,000$ were also ordered (University of Ilorin Library, World Bank File 1990).

There were prolonged delays in the efforts to reinstate the journals. In a meeting of professional library staff, the university librarian (University of Ilorin Library, Serials Unit, World Bank File 1991) said: "It may not be possible to get journals for 1991 through the procurement agents; as a result the University Library took a safety measure and placed order for some titles using UNESCO coupons."

In a related development, it was reported that the 500 journal titles ordered with the World Bank loan would likely not arrive until February or March 1992. Then, in a meeting held on September 23, 1991, the university librarian revised that estimate. He explained that only 20 journals had arrived and that few more should be expected by February or March 1992. He opined that the situation might change for the better by the end of 1992. There were also difficulties with the backfiles order. The National Universities Commission directed individual university libraries to hold local votes to determine which backfiles should be ordered. The backsets were to cover 1992. Thus, it was decided to cancel the original backfiles order with the World Bank.

Before the end of 1993, bureaucratic procedures had bogged down the smooth procurement of journals and only 44 titles had been received. Consequently, the rest of the orders were canceled. A new directive and new procedures were issued from the office of the World Bank Implementation Committee at the National Universities Commission. Fresh orders from the individual universities were to be prepared and submitted on deadline. This marked the end of the first attempt to reinstate canceled journals.

\section{The SEcond ATTEMPT}

The procedures used in the second attempt to reinstate the pruned journals differed in several ways from those of the first. The attempt would include the purchase of backfiles from 1993 forward. In addition, the mechanics of the reinstatement were handled by the university librarian and the serials unit of the library. Lists of previously canceled journals were compiled on a departmental basis, following the rating pattern adopted during the cancellation exercise that took place in 1987. The lists were sent to departments for rapid ranking because of time constraints. There was room for faculty to recommend new titles and to suggest reinstatement of any titles that had been previously canceled.

The ranking was done primarily by heads of departments, but in a few instances by deans of faculties. The university and serials librarians, assisted by the serials staff, coordinated this process. The exercise was conducted in March 1994 and resulted in the selection of 287 titles at an estimated cost of $\$ 86,952.55$. The list was dispatched to the National Universities Commission on schedule. However, the commission later requested that the University prepare a supplementary list for a specified amount. This list was to be arranged by discipline. The University of Ilorin Library was not the only one asked to supply a supplementary list; the com- 
TABLE 1

Titles Reinstated on FaCUlty Basis (SuPplementary)

\begin{tabular}{lcc}
\hline Faculty & No. Titles & Cost (\$) \\
\hline Science & 8 & 5,149 \\
Business and Social Sciences & 15 & 1,635 \\
Agriculture & 14 & 2,132 \\
Education & 15 & 2,229 \\
Engineering & 23 & 7,221 \\
Arts & 22 & 1,336 \\
'Health Sciences & - & - \\
\hline
\end{tabular}

Source: University of Ilorin Library. Serials Unit, World Bank File.

'No medical titles were listed uncler the supplementary list because the faculty was adequately provided for in the first list.

mission requested them from all university libraries that had failed to meet the commission's fiscal ceiling. The library came up with an additional 97 titles; thus the first list and the supplementary totaled 384 titles.

\section{Progress Report on Journal Supply}

As of January 31, 1995, 71 of the journal titles ordered during the second reinstatement attempt have been received. Added to the 44 titles received earlier, 115 titles have been received for 1993 subscriptions. These journals were supplied by Low Priced Books Limited, whose contract has been terminated. The breakdown of journals supplied by the agent is shown in table 2.

A new agreement was signed with Blackwell's Safari, which also supplies books through the World Bank Project.
Blackwell's first shipment of journals for 1994 subscriptions came in March 1995. It contained 263 journal titles. In May 1995, the agent made another delivery containing 67 journal titles for 1994, bringing the total received to 330 titles. It is clear from this that the agent was unable to supply 54 of the titles that had been ordered. No 1995 subscriptions had been received as of May 1995.

\section{Factors Affecting Reinstatements}

The university librarian consulted exclusively with the heads of departments in deciding what titles to reinstate or add. Some departments rated more than the required or requested number of titles, and many titles were graded by more than one department; in some cases these gradings conflicted with one another. The library also considered the price of titles

TABLE 2

Journal Titles Supplied by LoW PRICEd Books Limited

\begin{tabular}{lcr}
\hline \hline S/N & No. Titles & \multicolumn{1}{c}{ Amount } \\
\hline 1 & 26 & $\$ 17,647.24$ \\
2 & 76 & $£ 23,554.06$ \\
3 & 10 & DFL $15,608.00$ \\
4 & 3 & SFr $8,541.00$ \\
Total & 115 & \\
\hline
\end{tabular}

Source: University of Ilorin Library. Serials Unit, World Bank File, 
when deciding which journals to delete, meaning that expensive titles were deleted.

\section{OBSERVATIONS}

Using only the rankings of department heads and deans of faculties led inevitably to some questionable deletions. However, with the huge volume of work involved and short time limit, there was no time to allow the faculty a second chance. Lists were required very quickly, and most of the data were collected hastily, with no time for validation except in a few cases where the university librarian had to contact department heads by telephone on related issues. The practice of not validating the information is quite understandable because the university librarian and the serials staff were under pressure and had to work extra hours to meet the deadline given by the National Universities Commission. Inevitably errors occurred, but not often enough to invalidate the outcome of the exercise. Overall, the procedures utilized during the cancellation and reinstatement process worked reasonably well, even though methodological faults existed.

If the arrangement adopted in preparing the supplementary list as presented in table 1 had been used in making the first list, the serials department would have had a better idea of what was being spent in each discipline. Such information is invaluable not only to the university librarian for decision making but also to other unit heads and academic librarians.

\section{Conclusion}

The library was forced by rising costs and government fiscal measures to cooperate with teaching departments in the task of reducing journal commitments. Neither side welcomed the operation and there were times when patience wore thin during the 1987 exercise. Journal reinstatements also proved difficult to implement due to a number of factors, including faulty administrative arrangements and bureaucratic tangles. The problem of backfiles acquisition is a riddle that remains unsolved.

Unfortunately, to identify the problem is not to solve it, and unless the cost of the University Libraryss journals stops increasing or the library's books and periodicals budget expands, the library may face more sacrifices after the World Bank funding ceases.

The natuseating effects of Nigeria's economic crunch on libraries are not hard to decipher: journal subscriptions and book acquisitions have been reduced. There is evidence of decline in the resources and services of libraries, hence the need to turn to the World Bank for help. Unless the federal government makes enough funds available after the expiration of the World Bank Project, the libraries will be back at the very point they found themselves in 1987. Unless this vital issue is properly considered, reinstatements are unlikely to continue.

\section{Works CITED}

Olorunsolit, R., and E. O. Ajileye. 1990. Periodical retrenchment at the University of Ilorin Library. Library review 39: 42-46.

Puccio, Joseph A. 1989. Serials reference work. Englewood, Colo.: Libraries Unlimited.

University of Ilorin Library. Serials Unit, World Bank File. 1991. Minutes of the meeting of professional library staff at the University of Ilorin, held on Friday, 6 December.

Ward, M. 1975. Observation of serials management in seventeen London-based libraries. Library Association record 77, no. 10: 243 . 